\title{
Making a difference to student employability through assessment
}

\section{Andy Hollyhead}

Birmingham City University, UK

Jon Curwin

Birmingham City University, UK

\section{Abstract}

Students will know some of the benefits and costs of an undergraduate degree. They will be told of the degree 'premium' and that, over a lifetime, they can expect to be better off. A university education will open doors to professions that will seem distant when completing school education. They will anecdotally hear stories about employers expecting a first or upper second. They will also know that some students will never pay back their loans. The reality is that an undergraduate degree can lead to a good job but this is not the case for all students as finding graduate level employment will be very challenging for some. We argue that courses should continually look at ways to enhance the employability of their students.

It is understandable that students will see good grades from assessment as the route to a good degree and ultimately to a good job. If assessment can also develop and evidence the skills valued by others, particularly employers, then further benefits are added. There are a number of ways that student employability can be supported, including: careers advice; jobs fairs; visiting speakers and possibly a placement opportunity. We argue that, additionally, assessment can make a difference and with thoughtful design can make an even bigger difference. It is the author's experience that if students are asked what they learnt on their course, they are likely to talk about the outcomes of assessment. If these outcomes also evidence the skills valued by the employer, then this will present a more persuasive response. Assessment is critical for all courses. If assessment can leave the student with outcomes, experience or artefacts that evidence a 'can-do' ability then we argue this must positively impact on employability. 
Keywords: Employability; assessment; student engagement; skills enhancement.

\section{Introduction}

It is unsurprising that undergraduates will say that they are working for a first or upper second classification. BIS (2016) statistics show:

Graduates that achieved an upper second in their degree had the highest employment rates, although graduates that achieved a first in their degree had the lowest unemployment rates; these findings held across both the working age and young populations. (Department for Business, Innovation and Skills (BIS), 2016, p. 25)

The BIS report also shows that young graduates (21 to 30 years) are more likely to be employed and are paid an average of $£ 6,000$ a year more than those with no degree but that this 'graduate premium' - the extra amount a graduate can expect for those three or more years of study - is narrowing. A degree can lead to a good job but not for all; the BIS report shows that one-third of all graduates in the working population are not doing a highskilled job (BIS, 2016, p.11).

Assessment can mean different things to different people: to staff it can confirm the expected learning; to students a proof of knowledge and skills; to an employer it can give credibility to a qualification. It can also be a motivator, give a sense of achievement and broaden horizons. We argue that it is just too important to be seen exclusively as a means of mark determination. We do see a place for a broad range of assessment methodologies but if we merely ask students to complete multiple choice tests or examinations - what can a student say to an employer about their course or themselves? In contrast, if part of the assessment was a statistical analysis of recent economic trends or a digital story, when asked about what they have learnt a student could say 'I will show you'.

Within the context of higher education, assessment is accepted as a significant driver of student behaviour (Rowntree, 1989; Kirkwood, 2009) and will convey what is valued and what leads to success. We argue that assessment should be designed to deliver fair and consistent results but deliberately give students the opportunity to develop and evidence 
their employability. Surely becoming more employable is going to be motivational for a student. Assessment needs to embrace that motivation and offer something that is relevant to their career aspirations and make them 'stand out from the crowd', as Brown (2004) suggests:

If we want our students to demonstrate employability when they graduate, our assignments need to be designed to be practice-based, whether in terms of the practice of being a researcher or applications to professional contexts such as being an artist, an accountant, a health practitioner or a quality surveyor. Rather than assessing a learner's ability to write about good practice, an effective assessment strategy would seek to measure how the student can put into practice the learning achieved. (Brown, 2004, p. 83)

We argue that employability and the opportunities it offers are too important to be addressed exclusively in one or two isolated modules. Traditionally, a final year project was seen as the major piece of work that would bring various disciplines together in an applied way. It is now the case that fewer students are taking a final year project and this might be their only practice-based module. In our view, employability needs to be embedded across a course and considered in the design of all modules, even if it is not directly included in all modules for good reason. The course needs to offer some kind of balance for the student in terms of skills and knowledge, with each module making some but not necessarily equal contribution to employability. It may also be the case that the course does offer the opportunities to develop the knowledge, skills and attributes valued by employers but students still need to find ways to articulate this. The use of an eportfolio, for example, can help the student present information in a way that aligns with online applications. However, we believe that more can be done and that good practice could be extended across a wider range of modules.

\section{What is employability?}

Employability is about the person as well as the qualification. How often do we hear that if you have the skills 'we can give you the on-job training you need'? In the joint report by the 
Confederation of British Industries and Universities UK, a positive attitude is seen as the factor underpinning successful employability skills, exemplified by:

...a 'can-do' approach, a readiness to take part and contribute, openness to new ideas and a drive to make these happen. (Confederation of British Industry, 2009, p.8)

Employability is a willingness to apply relevant skills and knowledge and can be defined in terms of:

... a set of attributes, skills and knowledge that all labour market participants should possess to ensure they have the capability of being effective in the workplace - to the benefit of themselves, their employers and the wider economy. (Confederation of British Industry, 2009, p.8)

However, the list of skills (which could be a box ticking exercise) may not make the applicant effective in a competitive job market. If employers see only identical skills paraded, how can they select the best matched candidate? We argue that candidates will have a mix of common and unique skills and it is those unique skills such as an international business language or a technical ability that make a difference. Curwin and Lawton (2015) argue that students need to do more than merely articulate a list of skills, like team working or numeracy:

These can be thought of as threshold skills; without which an applicant will struggle to compete. If being uniquely good is important, then the applicant needs to be advised to evidence these threshold skills but they will also need to be advised to evidence all those attributes, characteristics and insights that make them special. To stand out an applicant will need to showcase those qualities and skills that make them different. (Curwin and Lawton, 2015, p.42)

In any competitive environment there is a pressure to match what others are doing, analogous to benchmarking in business. However, the driver is not merely equivalence but the achievement of competitive advantage. This comes from exceeding threshold competencies in one or more ways. These ways can often come from natural advantages 
like location and inherited skill sets. For an individual, it might come from an existing interest in fashion or language skills picked up as a child. The important point is that to be competitive is not just a matching of what others can do but also demonstrating other qualities that make the individual stand out. Recent interviews with employers have confirmed that offering an additional language, keeping a blog over an extended period and being able to take an old car engine to pieces and get it back together have all made a difference. We argue that assessment should allow a student to evidence difference as well as sameness.

\section{How can assessment make a difference?}

According to Race assessment is:

...the most important thing that happens to you in higher education. (Race, 2001, p.3)

Assessment can be fair, consistent and objective but add little to employability. If courses all offer homogenised curricula structure and content (and outcome), how can we expect students to evidence their unique qualities? If assessment becomes a series of standardised tasks such as multi-choice tests and examinations that require the application of existing knowledge or a coursework that critically reviews a case-study, a student can struggle to stand out. Employability is more than a complete CV. If all we are going to ask students to do is replicate a model CV, they (and we) are likely to miss the point that employability is more complex and is about the development and special qualities of the individual. Employability is about being more insightful, more experienced, evidencing the development of new and transferable skills, being aware of new knowledge and being sensitive to others. The advice we give needs to match the complexity of making the employability case.

The CareerEdge model of employability developed by Dacre Pool and Sewell (2007) (shown in Figure 1) uses: career development learning; experience (work and life); generic skills; degree subject knowledge, skills and understanding; and emotional intelligence as the building blocks of employability. The ability to reflect and evaluate will impact on selfesteem, self-efficacy and self-confidence - all of which are supported within this model of 
employability. Assessment can be informed by these 'building blocks', reflection and evaluation.

Figure 1. The CareerEdge model (Dacre Pool and Sewell, 2007).

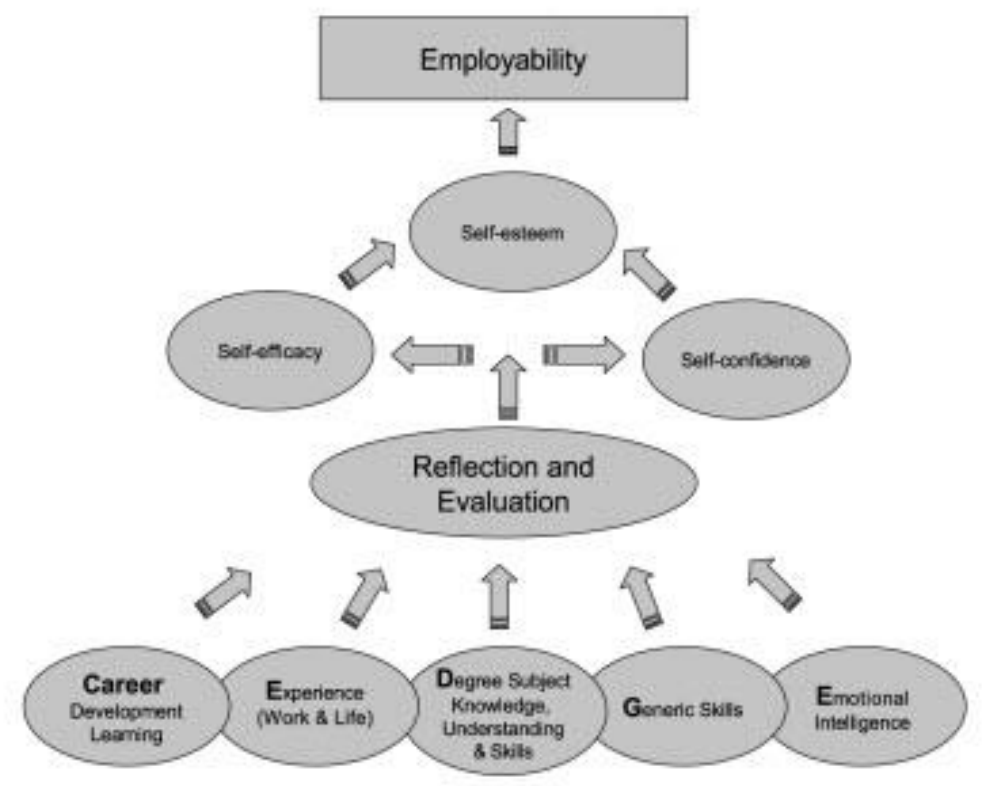

Some examples of how assessment and other activities can engage the student with the components of the model (shown in Figure 1) are given in the table below.

Table 1. Course responses and examples for the CareerEdge model.

\begin{tabular}{|l|l|l|}
\hline Component & Possible course response & Examples \\
\hline $\begin{array}{l}\text { Career development } \\
\text { learning }\end{array}$ & $\begin{array}{l}\text { - Find ways for students to } \\
\text { become more self-aware, } \\
\text { identify things they enjoy } \\
\text { doing and motivate them }\end{array}$ & $\begin{array}{l}\bullet \text { Mock interviews } \\
\text { - Feedback on CV } \\
\text { - Talks from alumni }\end{array}$ \\
\hline Experience (work and life) & $\begin{array}{l}\text { - Guide students in terms } \\
\text { of work and wider-life } \\
\text { experiences }\end{array}$ & $\begin{array}{l}\text { - Placements } \\
\text { - In-company } \\
\text { projects } \\
\text { Organisational } \\
\text { visits }\end{array}$ \\
\hline Generic skills & $\begin{array}{l}\text { Develop an explicit } \\
\text { strategy to enhance these } \\
\text { skills over the length of } \\
\text { the course }\end{array}$ & $\begin{array}{l}\text { Skills audit and } \\
\text { evaluation }\end{array}$ \\
\hline
\end{tabular}




\begin{tabular}{|c|c|c|}
\hline Component & Possible course response & Examples \\
\hline & $\begin{array}{l}\text { Ensure skills are also } \\
\text { embedded across the } \\
\text { range of modules }\end{array}$ & $\begin{array}{l}\text { - e-Portfolio such as } \\
\text { Mahara and } \\
\text { Pebblepad }\end{array}$ \\
\hline $\begin{array}{l}\text { Degree subject knowledge, } \\
\text { skills and understanding }\end{array}$ & $\begin{array}{l}\text { - Find ways for } \\
\text { assessment to do more } \\
\text { than just give a mark }\end{array}$ & $\begin{array}{l}\text { - Create short video } \\
\text { - Digital stories }\end{array}$ \\
\hline Emotional intelligence & $\begin{array}{l}\text { Recognise the } \\
\text { importance of emotional } \\
\text { intelligence and make this } \\
\text { explicit within the } \\
\text { rationale for this course }\end{array}$ & $\begin{array}{l}\text { - Peer assessment } \\
\text { - Team working }\end{array}$ \\
\hline
\end{tabular}

\section{An example of innovative assessment}

All assessment will carry some cost. Ideally, the assessment provides a challenge for the student, can confirm expected learning and be cost effective in terms of marking. Birmingham City Business School offers a level five module 'Creative Problem Solving' within the business range of courses. The focus of the module is the recognition, definition and redefinition of a problem of importance to the individual student, e.g. employability. Students are presented with models of the creative problem solving process and can make a choice about how they proceed. Essentially, students work on their own and in groups, to manage the problem solving process creatively. Their summative assessment is to report and reflect upon the outcomes achieved using a digital story of three to five minutes. A digital story is a snippet of video that brings together images and voice. Typically, we do not see a nervous individual talking to camera (but a digital story can include some of this) but a story told alongside the richness of pictures. The assessment allows students to enhance their skills in the use of modelling, the management of creative problem solving techniques, producing options and justifying choice as specified by the learning objectives. The assessment also allows the student to demonstrate unintended outcomes such as the imaginative use of video, artistic images and insightful fact-finding. In this case, the assessment does deliver the engagement with problem solving skills, is time effective to mark but also can make a practical difference to student employability. Individual modules can make a difference, but synergy will be realised if activities across modules are complementary. A digital story could be added to an e-portfolio alongside other content from the course. An articulation of such work, as facilitated by e-portfoilio software such as 
Mahara or Pebblepad for example, prepares the type of content necessary for a professional presence on social media or online application. Assessment in this context can be a mechanism to build confidence to present a persuasive argument to others.

\section{Conclusion}

The process of becoming more employable as an undergraduate is an important one and should, in itself, be motivational to the student. It will give a relevance to the course when it is known that others will value it. Assessment provides a signal to the student of what is valued and the outcomes of assessment, a record of achievement. Achievements over the course can provide students with outcomes and artefacts that they can take forward to employers as evidence that they can do and have a 'can-do' attitude. Individual modules, such as the 'Creative Problem Solving' module (given as an example above) can make a difference but it is our view that employability needs to be embedded throughout a course. It is our experience that looking at assessment across the course will provide assurance that the outcomes are an effective measure of achievement. Additionally, this review could also provide students with evidence of knowledge, skills and attributes that will make a difference for them in the workplace. This does not mean that employability begins to dominate all we do but rather the awareness is there and a proportionate response given.

\section{References}

Brown, S. (2004) 'Assessment for learning', Learning and Teaching in Higher Education, 1(1), pp. 81-89. (Not available online).

Confederation of British Industry, Universities UK (2009) Future fit: preparing graduates for the world of work. Available at: http://www.universitiesuk.ac.uk/policy-andanalysis/reports/Pages/future-fit-preparing-graduates-for-the-world-of-work.aspx (Accessed: 11 November 2017).

Curwin, J. and Lawton, R. (2015) 'The challenge of uniqueness - employability in higher education', Rapport - The International Journal for Recording Achievement, Planning and Portfolios, 1(1), p. 43 [Online]. Available at: 
https://view.joomag.com/rapport/0727239001439797282?page=43 (Accessed: 29 October 2017).

Dacre Pool, L. and Sewell, P. (2007) 'The key to employability: developing a practical model of graduate employability', Education+ Training, 49(4), pp. 277-289. https://doi.org/10.1108/00400910710754435

Department for Business, Innovation and Skills (BIS) (2016) Graduate Labour Market Statistics: 2015. Available at: http://dera.ioe.ac.uk/26145/1/bis-16-232-graduatelabour-market-statistics-2015.pdf (Accessed: 21 March 2017).

Kirkwood, A. (2009) 'E-learning: you don't always get what you hope for', Technology, Pedagogy and Education, 18(2), pp. 107-121. https://doi.org/10.1080/14759390902992576

Race, P. (2001) Assessment: a guide for students, Learning and Teaching Support Network Generic Centre. Available at: https://phil-race.co.uk/wpcontent/uploads/Assessment_guide_for_students.pdf (Accessed: 29 October 2017).

Rowntree, D. (1989) Assessing students: how shall we know them? $2^{\text {nd }}$ revised edn. London, Kogan Page.

\section{Author details}

Andy Hollyhead is an Associate Professor at Birmingham City Business School, Birmingham City University. (Email: andrew.hollyhead@bcu.ac.uk)

Jon Curwin is an Associate Professor at Birmingham City Business School, Birmingham City University. (Email: jon.curwin@bcu.ac.uk) 